\title{
Implementasi Pola Pembinaan dalam Masa Pengenalan Lingkungan Warga Binaan di Lembaga Pemasyarakatan Kelas II A Banceuy
}

\author{
Renaldy Caesar Adytama Putra \\ Politeknik Ilmu Pemasyarakatan \\ Correspondence email: renaldycaesar20@gmail.com
}

\begin{abstract}
Abstrak. Tindakan penyimpangan yang terjadi di masyarakat, berakibat terhadap banyaknya kasus kriminalitas yang terjadi. Dalam hal ini diperlukan adanya penegakan hukum berdasarkan peraturan perundang-undangan, serta adanya lembaga permasyarakatan selaku pelaksana penegakan hukum. Sebagai upaya penanggunlangan penimpangan sosial perlu dilakukan adanya pembinaan terhadap narapidana. Tujuan penelitian ini untuk mengetahui, implementasi program pada pembinaan tahap awal yang dilakukan di unit pelaksana teknis lembaga pemasyarakatan kelas II A Banceuy melalui masa pengenalan lingkungan (mapenaling) yang bertujuan agar narapidana baru dapat menyesuaikan dan mengenal lingkungannya sehingga para narapidana dapat terbiasa dengan pola hidup yang akan dijalani selama masa pidana. Kegiatan mapenaling tersebut dilakukan kurang lebih 1 ( satu ) bulan sesuai dengan PP nomor 31 tahun 1999. Metode penelitian dilakukan menggunakan metode survey. Subjek Penelitian berasal dari Petugas Pemasyarakatan yang bertugas di Lembaga Pemasyarakatan kelas IIA Banceuy. Sedangkan objek Penelitian ini berasal dari proses pembinaan warga binaan pemasyarakatan yang dilakukan di Lembaga Pemasyarakatan kelas IIA Banceuy. Narasumber dari penelitian ini adalah petugas pemasyarakatan dan warga binaan pemasyarakatan yang ada di Lembaga Pemasyarakatan kelas IIA Banceuy. Penelitian ini dilakukan melalui kuesioner yang disebar pada setiap warga binaan lembaga permasyarakatan dan petugas yang ada di Lembaga Pemasyarakatan kelas IIA Banceuy. Sumber data berasal dari pustaka dan lapangan yakni dari berbagai buku dan literature, laporan-laporan, jurmal penelitian dan artikel-artikel yang di publikasikan yang memiliki keterkaitan dengan penelitian ini. Selanjutnya, metode pengambilan data berasal dari catatan data pustaka kemudian mengolah bahan penelitian. Hasil dari penelitian menunjukkan bahwa proses pelaksaaan mapenaling masih belum optimal dan terdapat beberapa faktor penghambat dalam proses pelaksanaan program mapenaling yang dilakukan di lembaga pemasyarakatan kelas IIA
\end{abstract}

Kata Kunci: Pembinaan Tahap Awal, Narapidana, Lembaga Permasyarakatan, Peraturan Undang Undang.

\begin{abstract}
Actions of deviations that occur in the community, resulting in many cases of crime that occurred. In this case, there is a need for law enforcement based on laws and regulations, as well as the existence of prison institutions as law enforcement officers. As an effort to overcome social deviations, it is necessary to provide guidance to inmates. The purpose of this study was to determine, the implementation of the program in the initial stages of coaching carried out in the technical implementation unit of Class II penitentiary facilities A Banceuy through a period of environmental introduction (mapenaling) which aims so that new inmates can adjust and recognize their environment so that prisoners can get used to the lifestyle will be served during the criminal period. Mapenaling activities are carried out for approximately 1 (one) month in accordance with PP number 31 of 1999 . The research method was conducted using the survey method. The research subjects came from the Correctional Officers who served in the Banceuy Class IIA Correctional Institution. While the object of this research comes from the process of fostering inmates in prison conducted at Class IIA Penitentiary in Banceuy. The informants of this study are correctional officers and correctional residents in Class IIA Penitentiary in Banceuy. This research was conducted through a questionnaire distributed to every citizen fostered by prison and officers in Class IIA Penitentiary in Banceuy. Sources of data come from literature and the field from various books and literature, reports, research journalists and published articles that have relevance to this research. Furthermore, the method of collecting data comes from library data records and then processes the research material. The results of the study indicate that the process of implementing mapenaling is still not optimal and there are several inhibiting factors in the process of implementing mapenaling programs carried out in class IIA correctional facilities
\end{abstract}

Keywords: Law Enforcement, Judge, Correctional Institution, Criminal Justice System.

\section{PENDAHULUAN}

Perilaku penyimpangan sosial yang terjadi dilingkungan masyarakat akan berdampak pada terganggunya keseimbangan kehidupan dalam masyarakat. Hal ini sejalan dengan Robert M.Z. Lawang (yang diakses dari https://zhernia.files.wordpress.com/2010/06/penyimpangan-sosial.pdf) mengatakan bahwa perilaku menyimpang adalah tindakan yang menyimpang dari norma-norma yang berlaku dalam suatu sistem sosial dan menimbulkan usaha dari pihak berwenang untuk memperbaiki perilaku yang menyimpang/ normal. sedangkan James Vander Zarden (yang diakses dari https://zhernia.files.wordpress.com/2010/06/penyimpangan-sosial.pdf) berpendapat bahwa penyimpangan merupakan perilaku yang oleh sejumlah orang dianggap sebagai hal yang tercela dan diluar batas toleransi. Sependapat dengan Robert M.Z. Lawang, Paul B. Horton menyatakan bahwa setiap perilaku yang dinyatakan sebagai pelanggaran terhadap norma-norma kelompok atau masyarakat disebut sebagai penyimpangan sosial. Berdasarkan beberapa pengertian di atas dapat disimpulkan bahwa perilaku menyimpang merupakan suatu perilaku seseorang atau beberapa orang masyarakat yang menyeleweng dari norma-norma atau aturan yang berlaku di masyarakat. Akibat dari 
penyimpangan sosial ini akan berdampak terhadap terganggunya ketidakharmonisan dalam masyarakat serta menganggu keamanan dan ketertiban di lingkungan sekitar. Sebagai upaya penanggulangan penyimpangan di masyarakat maka diperlukan adanya penegakan hukum guna memberian sanksi serta pembinaan terhadap pelaku penyimpangan.

Untuk menanggulangi penyimpangan sosial yang dilakukan oleh sesorang atau beberapa orang masyarakat, diperlukan adanya lembaga penegak hukum sebagai wadah untuk memberikan tindakan baik sanksi maupun pemberian pembinaan terhadap para pelaku tindak penyimpangan sosial. Di Indonesia penegakan hukum dilakukan oleh beberapa lembaga diantaranya: kepolisian selaku lembaga pertama yang menanggani kasus tindakan kriminal yang terjadi di masyarakat memilki tugas untuk melakukan proses penyidikan, setelah proses penyelidikan dilakukan langkah selanjutnya dilakukan oleh pihak kejaksaan untuk mengurusi penuntutan yang akan diberikan kepada tersangka tindak kriminal, tahapan selanjutnya, mengenai penjatuhan vonis hukuman atau pidana akan dilakukan oleh lembaga kehakiman. Apabila seorang atau beberapa orang masyarakat terbukti melakukan tindakan kriminalitas dan telah diberikan vonis hukuman atau pidana, kehidupan narapidana selama didalam lapas akan diurusi oleh lembaga pemasyarakatan. Di dalam lembaga permasyarakatan perlakuan yang didapat oleh narapidana saat dalam vonis hukuman tidak hanya mencakup hukuman di dalam sel tahanan, tetapi lembaga permasyrakatan juga bertugas untuk memberikan pembinaan baik pembinaan secara fisik, kemandirian maupun pemberiaj pendidikan. ${ }^{1}$ Perihal tersebut sesuai dengan peraturan UU RI No.12 tahun 1995 tentang pemasyarakatan, mengenai pemerintah yang membentuk pemasyarakatan untuk melandasi tugas dan fungsi dari Lembaga Pemasarakatan itu senidri. ${ }^{2}$

Lembaga pemasyarakatan ialah komponen pelaksana teknis untuk melaksanakan pembinaan pada narapidana yang sedang menjalani vonis didalam lembaga permasyarakatan tersebut. Hal tersebut seperti yang disebutkan pada pasal 1 ayat 3 UU No. 12 tahun 1995 tentang pemasyarakatan. (Peraturan pemerintah nomor 31 tahun 1999, 1999). Sehingga lembaga pemasyarakatan mempunyai kewajiban untuk melakukan kegiatan pembinaan kepada setiap warga binaan pemasyarakatan. Selain itu terlibatnya lembaga pemasyarakatan dalam suatu system peradilan pidana (criminal justice system) menjadikan pemasyarakatan sebagai ujung tombak pelaksanaan pembinaan yang berupaya untuk mengembalikan kesatuan hidup, kehidupan dan penghidupan bagi setiap narapidana melalui redukasi, rehabilitasi, dan reintregrasi.

Dalam UU no. 12 tahun 1995 pasal 2 disebutkan bahwa "Sistem pemasyarakatan diselenggarakan dalam rangka membentuk Warga Binaan Pemasyarakatan agar menjadi manusia seutuhnya, menyadari kesalahan, memperbaiki diri, dan tidak mengulangi tindak pidana sehingga dapat diterima kembali oleh lingkungan masyarakat, dapat aktif berperan dalam pembangunan, dan dapat hidup secara wajar sebagai warga yang baik dan bertanggung jawab". (Sistem pembinaan, 2013) .

Sebagaimana yang dijelaskan oleh Dwi Djaprianto bahwa "Lembaga Pemasyarakatan sejatinya adalah sebagai ujung tombak pelaksanaan pembinaan dan sebagai asas penaungan bagi masyarakat melalui pendidikan, rehabilitasi, dan reintregrasi". ${ }^{8}$ Oleh sebab itu tujuan utama dari pembinaan yang dilakukan oleh Lembaga Pemasyarakatan adalah agar narapidana tidak mengulangi lagi perbuatannya dan bisa menemukan kembali kepercayaan dirinya serta dapat diterima menjadi bagian dari anggota masyarakat ${ }^{4}$.

Salah satu lembaga permasyarakatan di Indonesia yakni lembaga permasyarakatan kelas II A Banceuy. Lembaga ini merupakan lembaga permsyarakatan yang diperuntukkan menampung narapidana kasus narkotika yang berasal dari kanwil Departemen Kehakiman DKI Jakarta dan Jawa Barat. Berdasarkan data lembaga permasyarakatan kelas II A Banceuy terdapat 1.083 warga binaan permasyarakatan (WBP). Hal ini menunjukkan bahwa masih terdapat banyak kasus penyimpangan sosial terutama tentang narkotika di kalangan masyarakat, penyimpanagn tersebut tidak hanya akan memunculkan keresahan bagi lingkungan masyarakat sekitar tetapi juga akan dapat mempengaruhi orangorang yang ada pada lingkungan tersebut. Salah satu upaya yang dapat dilakukan dalam mengatasi penyimpangan sosial yaitu dengan memberikan sanksi yang tegas guna memberikan efek jera terhadap pelaku kriminalitas, selain itu juga diperlukan pemberikan sosialisasi mengenai dampak penyimpangan sosial sehingga akan menyadarkan pelaku tindak kriminalitas atas kejahatan yang telah dilakukan, serta melakukan rehabilitasi sosial. Sebagai upaya penanggulangan atas tindak kriminalitas yang telah dilakukan, lembaga permasyarakatan memilki peranan penting dalam melangsungkan pembinaan kepada warga binaan permasyarakatan.

Menurut peraturan UU RI No.12 Tahun 1995 yang mengatur tentang Pemasyarakatan Pasal 1 Ayat 1, disebutkan bahwa Pemasyarakatan merupakan aktivitas yang dilakukan oleh lapas maupun rutan untuk pemberian pembinaan terhadap Warga Binaan Pemasyarakatan berdasarkan sistem, kelembagaan. Program pembinaan yang diberikan bukan

\footnotetext{
Sarli Zulhendra, Panduan Hukum: pengetahuan tentang aparat Penegak Hukum. http://www.solider.or.id/2014/07/14/panduan-hukum-pengetahuan-tentang-aparat penegak hukum

${ }^{2}$ Undang-Undang Republik Indonesia No.12 Tahun 1995, Tentang Pemasyarakatan.

${ }^{3}$ Sistem pembinaan. (2013, maret 12). hal. http://repository.unpas.ac.id/14819/4/BAB\%20II.pdf.

${ }^{4}$ Dwidja Priyanto, Sistem Pelaksanaan Pidana Penjara di Indonesia, (Bandung: PT. Rifka Aditama, 2009), hlm. 103.
} 
merupakan bagian akhir dari sistem pemidanaan dalam tata peradilan pidana.Lembaga Pemasyarakatan melaksanakan kegiatan pembinaan terhadap warga binaan melalui 2 jenis pembinaan, yaitu pembinaan kepribadian dan kemandirian (Keputusan Menteri Kehakiman Republik Indonesia No: M. 02-PK.04.10 Tahun 1990). Pembinaan kepribadian dapat dilakukan melalui pembinaan kerohanian yakni sebagai upaya mendekatkan narapidana dengan Tuhan, agar mereka dapat menyadari kesalahan yang telah dilakkan. Sedangkan pembinaan kemandirian dilakukan dengan cara meberikan keterampilan atau mengolah skil dari setiap diri para narapidana.

Pembinaan secara umum dapat diartikan sebagai seuah proses yang dilakukan kepada pelaku tindak kriminalitas dengan peralatan, uang, waktu, metode, dan sistem sesuai dengan prinsip yang ada untuk sebagai usaha menggapai tujuan yang telah ditentukan. Pengertian lain dari "pembinaan" adalah segala bentuk usaha atau tindakan yang berhubungan secara langsung dengan proses perencanaan pelaksanaan proses pembinaan, penyusunan tahapan dalam proses pembinaan, pembangunan atau pengembangan atas pembinaan yang dilakukan, pemberian pengarahan terhadap warga binaan permasyarakatan, pengendalian atas proses pembinaan secara berdaya guna dan berhasil guna ${ }^{5}$.

Meskipun telah dibentuk sistem pemasyarakatan, tidak berarti sewaktu-waktu pelaku tindak krminalitas tidak akan melakukan kesalahan atau kekhilafan kembali sehingga pelaku akan mendapatkan sanksi pidana kembali. Pemberian sanksi pidana terhadap pelaku tindak kriminalitas akan memberikan efek jera, pemberian pembinaan yang telah diberikan lembaga permasyarakatan juga harus didukung oleh lingkungan masyarakat sekitar. Hal tersebut dapat dilakukan dengan tidak mengucilkan pelaku tindak kriminalitas yang telah bebas dari hukuman pidana, sehingga pelaku akan merasa bahwa ia dapat diterima kembali ditengah-tengah masyarakat. Hal ini sebagai upaya pemberian motivasi terhadap pelaku yang telah bebas untuk bisa menjadi manusia yang lebih baik dan memilki pribadi yang berintegritas. Menurut Adi Sujatno, faktor-faktor yang menyebabkan WBP berbuat hal yang kontradiktif dengan hukum, agama, kesusilaan, atau kewajiban-kewajiban sosial lain yang dapat dikenakan pidana"6.

Dibentuknya lembaga permasyarakatan merupakan upaya dalam pemebentukan warga binaan permasyarakatan supaya dapat menyadari kesalahan yang mereka lakukan, sehingga mereka dapat melakukan perbaikan diri dan tidak mengulangi kesalahan yang sama, demi menjadikan mereka sebagai pribadi yang berintegritas. Berhasil tidaknya pencapaian tujuan dari sebuah sistem peradilan pidana yang hendak dicapai dalam upaya menekan tingkat kejahatan serta menciptakan kesejahteraan masyarakat tidak hanya ditentukan oleh sub sistem peradilan pidana seperti kepolisian, kejaksaan dan pengadilan namun pemasyarakatan juga berperan sebagai pelaksana pidana khususnya pidana penjara.

Dalam program pembinaan dibagi menjadi 3 (tiga) tahapan pembinaan yaitu :

1. Tahap awal

Setiap Narapidana yang masuk di dalam Lembaga Pemasyarakatan akan diintrogasi untuk mendeteksi segala hal ihwal dirinya, tergolong sebab Narapidana melakukan pengingkaran. Selain itu gambaran perihal narapidana dapat diperoleh dari pihak keluarga, bekas majikan atau atasannya, teman sekerja, korban dari pelaku tindak kejahatan, maupun dari petugas instansi lain yang telah menangani perkaranya. Pembinaan pada tahap ini disebut pembinaan tahap awal, di mana kegiatan masa pengamatan, penelitian dan pengenalan lingkungan untuk menentukan perencanaan pelaksanaan program pembinaan kepribadian dan kemandirian yang waktunya dimulai pada saat yang bersangkutan berstatus sebagai narapidana sampai dengan 1/3 (satu per tiga) dari masapidana. Pembinaan pada tahap ini masih dilakukan dalam Lembaga Pemasyarakatan dan pengawasannya maksimun.

2. Tahap lanjutan

Pembinaan tahap lanjutan terbagi menjadi dua yaitu :

a. Tahap lanjutan pertama, sejak berakhirnya pembinaan tahap awal sampai dengan $1 / 2$ (satu per dua) dari masa pidana. Pada tahap ini pembinaan masih dilaksanakan di dalam Lembaga Pemasyarakatan dan pengawasannya sudah memasuki tahap medium-security.; dan

b. Tahap lanjutan kedua, sejak berakhirnya pembinaan tahap lanjutan pertama sampai dengan 2/3 (dua per tiga) masa pidana. Dalam tahap lanjutan ini Narapidana sudah memasuki tahap Asimilasi dan selanjutnya dapat diberikan pembebasan bersyarat atau cuti menjelang bebas dengan pengawasan minimum security. (Peraturan pemerintah nomor 31 tahun 1999, 1999)

3. Tahap akhir

Dilaksanakan sejak berakhirnya tahap lanjutan sampai dengan berakhirnya masa pidana dari narapidana yang bersangkutan. Pembinaan ini merupakan kegiatan berupa perencanaan dan pelaksanaan program integrasi yang dimulai sejak berakhirnya tahap lanjutan sampai dengan berakhirnya masa pidana dari Narapidana yang bersangkutan. Pembinaan pada tahap ini, bagi Narapidana yang telah memenuhi syarat untuk diberikan cuti Menjelang Bebas atau Pembebasan Bersyarat dan pembinaannya dilakukan di luar Lembaga Pemasyarakatan oleh Balai Pemasyarakatan yang kemudian disebut Pembimbing Klien Pemasyarakatan. Pembimbingan adalah pemberian

5 Tim Peneliti BPHN dan FISIP UI, 1988, Aspek-aspek yang Mempengaruhi Penerimaan Bekas Narapidana dalam Masyarakat. Laporan Penelitian, Jakarta: Badan Pembinaan Hukum Nasional Departemen Kehakiman, hlm. 16

${ }^{6}$ Adi Sujatno, 2008, Pencerahan di Balik Penjara, Jakarta: Sinar Grafika. 
tuntunan untuk meningkatkan kualitas ketaqwaan terhadapa Tuhan Yang Maha Esa, intelektual, sikap dan prilaku profesional, kesehatan jasmani dan rohani Klien Pemasyarakatan ${ }^{7}$.

Berdasarkan ketentuan Pasal 6 UU No. 12 Tahun 1995, dinyatakan bahwa: Pembinaan warga binaan pemasyarakatan dilakukan di Lembaga Pemasyarakatan dan pembimbingan warga binaan pemasyarakatan dilakukan oleh Balai Pemasyarakatan sedangkan pembinaan di Lembaga Pemasyarakatan dilakukan terhadap Narapidana dan Anak Didik Pemasyarakatan.

Pembinaan WBP di Lembaga Pemasyarakatan dibagi dalam dua hal. Pola pembinaan yang dilakukan di dalam Lembaga Pemasyarakatan disebut asimilasi, yaitu suatu proses pembinaan terhadap warga binaan pemasyarakatan yang telah memenuhi persyaratan tertentu dengan membaurkan mereka ke dalam kehidupan masyarakat. Sedangkan pembinaan yang dilakukan di luar Lembaga Permasyarakaan, dilakukan oleh Balai Pemasyarakatan yang disebut integrasi, yaitu proses pembimbingan terhadap warga binaan pemasyarakatan yang telah memenuhi persyaratan tertentu untuk hidup dan berada kembali di tengah-tengah masyarakat dengan bimbingan dan pengawasan Balai Pemasyarakatan.

Pengalihan pada setiap tahapan pembinaan tersebut ditetapkan melalui sidang tim pengamat pemasyarakatan yang berdasarkan data berupa hasil dari pengamatan, penilaian, dan laporan terhadap pelaksanaan pembinaan.

1. Pembinaan tahap awal yang sebagaimana dimaksud dalam Pasal 9 ayat (1) PP 31 tahun 1999 meliputi:

a) Masa pengamatan, pengenalan dan penelitian lingkungan paling lama 1 (satu) bulan, tahapan ini sebagai upaya pengenalan terhadap narapidan baru agar mampu beradaptasi dengan lingkungan dalam lembaga permasyarakatan

b) Perencanaan program pembinaan kepribadian dan kemandirian, tahapan ini dilakukan dengan menyusun perencanaan yang akan diberikan dalam program pembinaan kepribadian dan kemandirian narapidana selama menjalani pidana di dalam lembaga permasyrakatan.

c) Pelaksanaan program pembinaan kepribadian dan kemandirian, sebagai tahapan penting untuk mengetahui hasil dari pemberian pembinaan serta sebagai upaya unruk pencapaian atas tujuan yang diiinginkan dan

d) Penilaian pelaksanaan program pembinaan tahap awal. (Peraturan pemerintah nomor 31 tahun 1999, 1999) ${ }^{8}$

2. Pembinaan tahap lanjutan sebagaimana dimaksud dalam Pasal 9 ayat (2) meliputi:

a) Perencanaan program pembinaan lanjutan;

b) Pelaksanaan program pembinaan lanjutan, sebagai tahapan lanjutan atas pelaksanaan program pembinaan yang telah dilakukan sebelumnya.

c) Penilaian pelaksanaan program pembinaan lanjutan; dan

d) Perencanaan dan pelaksanaan program asimilasi.

3. Pembinaan tahap akhir sebagaimana dimaksud dalam Pasal 9 ayat (3) meliputi:

a) Perencanaan program integrasi;

b) Pelaksanaan program integrasi; dan

c) Pengakhiran pelaksanaan pembinaan tahap akhir. (Peraturan pemerintah nomor 31 tahun 1999, 1999)

Pembinaan yang dilakukan disisi lain bertujuan untuk mendeportasi Warga Binaan Pemasyarakatan (WBP), selain itu upaya melindungi masyarakat terhadap kemungkinan diulanginya tindak pidana oleh warga binaan pemasyarakatan.

Program pembinaan di dalam Lembaga Pemasyarakatan kelas IIA Bancey berfokus pada pembinaan tahap Mapenaling. Dalam program mapenaling narapidana akan dipaksa masuk dalam pola hidup yang penuh dengan aturan seperti bangun pagi, mengaji, sholat berjamaah bagi narapidana yang beragama Islam, dan semua aturan yang ada di Lembaga Pemasyarakatan, dengan program tersebut bertujuan agar narapidana dapat terbiasa dengan perilaku hidup yang baik serta potensi dan kebutuhan narapidana dapat diketahui. Selama masa pengenalan lingkungan (mapenaling) narapidana dicabut haknya untuk dapat dikunjungi oleh keluarganya serta memanfaatkan fasilitas yang tersedia. Sehingga proses interaksi narapida tersebut hanya terjadi dengan sesama narapidana di dalam kamar mapenaling atau kamar karantina yang posisinya berada di blok A dan terpisah dengan blok hunian lainnya. Setelah menjalani mapenaling para narapidana tersebut akan dipindahkan kedalam sel-sel dan ditempatkan dalam blok hunian bergabung dengan para narapidana lainnya sesuai dengan tindak pidana yang dilakukannya.

Berdasarkan data yang ada jumlah narapidana per 8 april 2020 mencapai 1.083 warga binaan yang berada di dalam lapas sedangkan kapasitas di lembaga permasyarakatan kelas II A banceuy hanya dapat menampung 913 warga

7. Priyatno. (2006). Sistem Pelaksanaan Pidana Penjara di Indonesia. Bandung: PT Refika Aditama.

${ }^{8}$. Peraturan pemerintah nomor 31 tahun 1999. (1999, january 31). Undang undang pemasyarakatan. Diambil kembali dari https://jdih.bpk.go.id/wp-content/uploads/2012/03/PP311999.pdf 
binaan. Hal tersebut menunjukkan bahwa jumlah warga binaan atau narapidana melebihi kapasitas kamar mapenaling sehingga menyebabkan over crowded dan bertambahnya jumlah narapidana dalam kurun waktu yang tidak tentu mengakibatkan waktu pelakasanaan mapenaling hanya dilakukan dalam satu minggu sehingga proses kegiatan mapenaling tidak dapat berjalan dengan efektif yakni tidak semua perencanaan program pembinaan kepribadian dan kemandirian dapat terlaksana dengan baik sementara itu program mapenaling ini sangat berguna untuk menilai dan mempengaruhi berhasil atau tidaknya pembinaan di tahap selanjutnya.

Berdasarkan keterangan yang disampaikan oleh petugas pemasyarakatan yang berada di lembaga Permasyarakatan Kelas II A Banceuy mengatakan bahwa pembinaan WBP yang dilaksanakan dirasa kurang efektif karena minimnya respon dari warga binaan pemasyarakatan. Selain itu kurangnya koordinasi dari petugas lapas kelas IIA banceuy dengan lapas, rutan atau pihak lainnya terkait dengan penerimaan tahanan atau narapidana baru yang menimbulkan pada penumpukan narapidana baru saat melaksanakan tahap mapenaling sehingga waktu pelaksanaan mapenaling berbeda-beda dan program pembinaan pada tahap mapenaling tidak dapat tersampaikan secara optimal. Selain itu perlu adanya dukungan dari petugas dalam pelaksanaan program mapenaling, baik dukungan yang bersifat finansial, moral, sarana, maupun prasarana dan memantau perkembangan narapidana selama mengikuti program mapenaling. Seperti adanya jadwal petugas yang dilakukan secara bergantian untuk memberikan pembinaan kepada narapidana baru.

Dengan latar belakang inilah, peneliti ingin mengkaji perihal Implementasi Pola Pembinaan Dalam Masa Pengenalan Lingkungan Warga Binaan Di Lembaga Pemasyarakatan Kelas Ii A Banceuy. Dalam hal ini harapan peneliti berharap agar mampu menjawab permasalahan mengenai bagaimana efektivitas pelaksanaan pembinaan warga binaan pemasyarakatan yang terjerumus dalam kasus narkotika, maupun faktor yang menjadi penghambat dalam proses pelaksanaan program masa pengenalan lingungan (mapenaling). Sehingga Warga Binaan Pemasyarakatan dapat mengalami perubahan tingkah laku supaya dapat bersosialisasi dimasyarakat dan menjadi warga binaan yang lebih baik.

\section{METODE PENELITIAN}

Metode penelitian dilakukan menggunakan metode survey. Metode ini dilakukan dengan cara penyelidikan secara langsung di lapangan untuk memperoleh fakta dari permasalahan yang ada berdasarkan kejadiaan yang sebenarnya. Subjek Penelitian berasal dari Petugas Pemasyarakatan yang bertugas di Lembaga Pemasyarakatan kelas IIA Banceuy. Sedangkan objek Penelitian ini berasal dari proses pembinaan warga binaan pemasyarakatan yang dilakukan di Lembaga Pemasyarakatan kelas IIA Banceuy. Narasumber dari penelitian ini adalah petugas pemasyarakatan dan warga binaan pemasyarakatan yang ada di Lembaga Pemasyarakatan kelas IIA Banceuy. Penelitian ini dilakukan melalui kuesioner yang disebar pada setiap warga binaan lembaga permasyarakatan dan petugas yang ada di Lembaga Pemasyarakatan kelas IIA Banceuy. Sumber data berasal dari pustaka dan lapangan yakni dari berbagai buku dan literature, laporan-laporan, jurmal penelitian dan artikel-artikel yang di publikasikan yang memiliki keterkaitan dengan penelitian ini. Selanjutnya, metode pengambilan data berasal dari catatan data pustaka kemudian mengolah bahan penelitian.

\section{HASIL DAN PEMBAHASAN}

Dalam kehidupan bermasyarakat penyimpangan sosial seringkali terjadi, adanya perilaku penyimpangan sosial tersebut dapat menimbulkan terganggunya keseimbangan kehidupan dalam masyarakat serta munculnya dampak negatif pada masyarakat sekitar. Penyimpangan sosial dalam lingkungan masyarakat dapat diatasi dengan pemberian pembinaan pada pelaku tindak kriminalitas. Proses pembinaan yang dilakukan meliputi tahapan perencanaan pembinaan, pelaksanaan pembinaan yang dapat dikatakan sebagai tahapan penting untuk penunjang keberhasilan dari pemberian dalam mencapai tujuan yang diiharapkan, terakhir yakni tahapan evaluasi pembinaan tahapan ini merupakan tahapan untuk melakukan penilaian program pembinaan yang telah dilaksanakan serta evaluasi untuk proses pembinaan selanjutnya agar dapat berjalan secara optimal dan tujuan dari pembinaan dapat dicapai. Proses pembinaan yang dilakukan di Lembaga Pemasyarakatan kelas IIA Banceuy yaitu berupa pengenalan lingkungan (mapenaling).

Mapenaling adalah program pembinaan tahap awal yang diberikan kepada setiap narapidana yang menjalani masa pidananya di lembaga pemasyarakatan. Program mapenaling tersebut sangat berguna terhadap pembinaan perilaku sosial narapidana, sehingga dapat dijadikan penentu berhasil atau tidaknya pembinaan pada tahap selanjutnya. Dalam proses pelaksanaannya diharapkan narapidana dapat tekun dalam mengikuti program pembinaan mapenaling sehingga pelaksanaan program dapat berjalan lebih maksimal, selain itu diharapkan narapidana dapat berpartisipasi secara aktif, serta mampu melaksanakan arahan dan bimbingan yang diberikan oleh pertugas pembimbing atas dengan baik. Ketika pelaksanaan program pembinaan yang dilakukan pada masa pengenalan lingkungan atau mapenaling ini berhasil, maka kedepannya narapidana akan mampu menyesuaikan diri dan terbiasa dengan program pembinaan yang dilakukan didalam Lapas. 
Pembinaan narapidana secara umum bertujuan menjadikan narapidana mampu berintegrasi dengan baik dalam masyarakat melalui pendekatan pemantapan ketahanan mental. Sedangkan tujuan khusus dari proses pembinaan narapidana diharapkan mampu mengukuhkan kembali martabat maupun kepercayaan diri serta bersikap optimis, dapat memperoleh pengetahuan serta keterampilan baru untuk bekal hidup di dalam masyarakat, agar dapat menjadi manusia yang patuh pada hukum, memiliki jiwa dan semangat pengabdian terhadap bangsa dan negara. Berdasarkan UU No. 12 Tahun 1995 tentang Pemasyarakatan terdapat beberapa tujuan pelaksanaan pembinaan narapidana di Lembaga Pemasyarakatan, yang pertama adalah memberikan pengalaman dan keterampilan. Pemerian pengalaman dan keterampilan ini bukan anya sebagai kewajiban narapidana selama lapas tetapi juga sebagai pengolahan keterampilan yang telah mereka miliki. Sehingga saat mereka keluar atau bebas dari pdana mereka tealah memilki bekal dari pengalaman selama di dalam lembaga permasyrakatan serta dapat menerapkan keterampilan mereka di dalam lingkungan masyarakat luar. Dengan demikian mereka akan bisa menjadi manusia yang mandiri dan akan memeperoleh kepercayaan kembali dari lingkungan masyarakat sekitar. Kemudian mengembalikan kemampuan dan motivasi para narapidana.(Kontribusi keberhasilan pembinaan narapidana di indonesia, 2016, hal. http://jurnalperspektif.org/index.php/perspektif/article/view/27) ${ }^{10}$. Pengembalian kemampuan dan motivasi terhadap para narapidana akan memberikan pengaruh positif untuk mampu mengembalikan rasa kepercayaan diri mereka sehingga dapat kembali diterima ditengah-tengah masyarakat sekitar.

Melalui tahapan pembinaan yang dilaksanakan di Lembaga Pemasyarakatan kelas IIA Banceuy diharapkan Warga Binaan Pemasyarakatan dapat menjadi manusia yang lebih baik, para narapidana dapat menyadari kesalahan yang telah diperbuat sehingga mereka dapat berintrospeksi diri serta tidak akan mengulangi tindak pidana yang pernah mereka lakukan sebelumnya. Pembinaan warga binaan pemasyarakatan yang dilakukan berjalan secara efektif. Pembinaan yang diberikan dalam beberapa tahapan yaitu pengenalan lingkungan, assessment, skrining kesehatan, pembinaan kepribadian. Dalam pembinaan kepribadian meliputi beberapa hal diantaranya kegiatan kerohanian, dan pemberian wawasan kebangsaan. Dalam kurun waktu yang singkat yaitu dilaksanakan selama satu minggu maka perlu jadwal rutin terkait program pembinaan yang akan diberikan kepada narapidana yang sedang manjalani tahap mapenaling seperti :

1. Pengenalan lingkungan yang akan dilakukan oleh petugas pembinaan meliputi:

a. Pembeberan tentang hak dan kewajiban, mencakup hak-hak yang diperoleh narapidana selama berada di lembaga permasyarakatan, kewajiban yang harus dilakasanakan oleh para narapidana.

b. Pengenalan terhadap peraturan dan ketentuan yang berlaku, hal ini mencakup tentang tata tertib larangan bagi para narapidana selama berada didalam lembaga permasyarakatan.

2. Dilakukannya assessment untuk mengetahui:

a. Tingkat resiko pengulangan pidana,

b. Minat, bakat, keterampilandan keahlian yang dimiliki oleh setiap narapidana,

c. Mengetahui latar belakang kehidupannya yang akan berguna terhadap perencanaan program pembinaan

3. Melakukan skrining kesehatan atau pemeriksaan kesehatan dasar bagi narapidana baru yang bertujuan untuk mengetahui riwayat kesehatan, serta merupakan bentuk deteksi dini terhadap resiko kesehatan sehingga dapat memberikan informasi sekaligus penanganan yang tepat jika ditemukan resiko terhadap penyakit tertentu. Hal tersebut juga dapat mempengaruhi terhadap penempatan kamar atau kegiatan pembinaan narapidana, contohnya bagi narapidana yang menderita penyakit TBC, HIV/AIDS, infeksi menular seksual,

4. Memberikan wawasan atau penyuluhan dalam bidang kesehatan seperti penyuluhan mengenai bahaya penggunaan narkoba, pencegahan terhadap penyakit menular, serta prilaku hudup sehat. Kegiatan tersebut merupakan upaya untuk mencegah penyakit yang dapat dialami oleh narapidana serta agar narapidana mengetahui dampak buruk dari penggunaan narkoba sehingga mereka akan membiasakan diri dengan prilaku hidup sehat.

5. Melakukan pembinaan pada aspek kepribadian pada program ini petugas yang menangani kegiatan mapenaling secara berkesinambungan melakukan kegiatan-kegiatan pembinaan yang bertujuan untuk merubah pola pikir dan kepribadian narapidana sehingga mereka dapat menyadari kesalahan, menerima keadaaan dirinya, dapat mengikuti program pembinaan dengan baik serta akan terbiasa dengan kehidupan yang akan dijalaninya. Upaya pembinaan yang menekankan terhadap aspek kepribadian juga dapat dilakukan melalui:
a. Kegiatankeagamaan
b. Kegiatanbaris-berbaris
c. Pramuka
d. Kesenian

\footnotetext{
${ }^{9}$ Kontribusi keberhasilan pembinaan narapidana di indonesia. (2016). umi enggarsasi. Kontribusi keberhasilan pembinaan narapidana di indonesia.

${ }^{10}$ Kontribusi keberhasilan pembinaan narapidana di indonesia. (2016). umi enggarsasi. Kontribusi keberhasilan pembinaan narapidana di indonesia.
} 


\section{e. Kegiatanjasmani}

Agar pelaksanaan program mapenaling dapat terlaksana secara maksimal dan sesuai dengan tujuan, maka diperlukan dukungan dari semua pihak-pihak yang terkait terutama seluruh petugas pemasyarakatan yang berada di lembaga pemasyarakatan kelas IIA banceuy, narapidana yang sedang menjalani masa pengenalan lingkungan (mapenaling), serta ahli dibidang kesehatan yang bertugas untuk melakukan pemeriksaan terhadap setiap narapidana dan dapat mendeteksi jika ada gangguan kesehatan yang dialami oleh narapidana.

Program pembinaan ini dilaksanakan secara langsung dengan melibatkan beberapa narapidana sehingga mereka dapat mengamati serta mencatat perilaku dan kejadian pada keadaan sebenarnya. Salah satu aktivitas wajib untuk diikuti selama menjalani masa pengenalan lingkungan adalah mengikuti kegiatan yang sudah dijadwalkan seperti, penyuluhan tata tertib, aturan-aturan, kesehatan dan pembinaan kepribadian. Setiap melakukan mapenaling ini kami selalu melakukan konfirmasi kembali dengan petugas agar informasi yang diperoleh tidak bertolak belakang dengan program pembinaan yang berlaku di lapas.

Proses pembinaan di lembaga pemasyarakatan kelas IIA banceuy dapat dilihat dari awal proses registrasi penerimaan narapidana. Kehadiran warga binaan permasyarakatan dalam proses ini menunjukkan bahwa adanya motivasi yang tinggi untuk dapat menjadi sebuah pribadi lebih baik serta berintegritas. Motivasi yang telah muncul dalam diri para warga binaan dapat memberikan penilaian positif terhadap program yang dilaksanakan oleh pihak lembaga permasyarakatan bahwasanya dengan kehadiran warga binaan selama proses mapenaling berarti keinginan warga binaan untuk berubah menjadi lebih baik telah ada dalam diri warga binaan. Hal ini sesuai dengan tujuan dari program pembinaan yang dilaksanakan. Selain itu pembinaan ini berfungsi mengetahui perkembangan mental, fisik, dan keterampilan yang mereka miliki. Keberhasilan dalam proses pembinaan tentunya didukung oleh beberapa faktor dimana hal tersebut sangat berperan penting dalam suatu proses pembinaan. Elemen penyokong yang menunjang proses pembinaan dapat berasal dari beberapa unsur seperti SDM yakni warga binaan itu sendiri, pemerintah, petugas lapas selaku pelaksana program pembinaan, dan masyarakat. Masyarakat turut berpengaruh terhadap pencapaian program pembinaan, karena masyarakat cenderung berasumsi negatif terhadap mantan narapidana yang telah bebas dari hukuman. Seringkali mereka merasa dkucilkan oleh lingkungan sekitar sehingga kepercayaan diri pada narapidana yang telah bebas akan berkurang. Tidak dipungkiri bahwa mereka akan mengulangi tindak kejahatan seperti sebelumnya.Selain faktor pendukung dari pihak terkait, faktor lain juga dapat bersifat sarana, maupun prasarana. Adanya fasilitas yang lengkap sebagai upaya penunjang dalam mengoptimalkan pelaksanaan program pembinaan.

Program mapenaling yang dilakukan di lembaga pemasyarakatan kelas IIA Banceuy dalam pelaksanaannya belum optimal, selain waktu pelaksaaan yang singkat hal tersebut juga dikarenakan masih adanya beberapa permasalahan yang ditemui, seperti :

1. Pembinaan yang dilakukan pada program mapenaling hanya terpaku dalam bidang kesehatan seperti pemeriksaan dasar, penyuluhan kesehatan berupa bahaya narkoba, HIV/AIDS, TBC yang dilakukan oleh bagian kesehatan di lembaga pemasyarakatan kelas IIA Banceuy.

2. Tidak ada petugas yang memonitoring secara langsung terhadap seluruh kegiatan mapenaling sehingga tidak semua program pembinaan dapat tersampaikan.

3. Waktu penerimaan narapidana yang tidak pasti atau tidak tentu serta kurangnya kapasitas kamar mengakibatkan waktu pelaksanaan mapenaling tidak dapat dilakukan dalam kurun waktu yang lama dan tidak dapat dilakukan dalam waktu yang sama.

4. Tidak adanya jadwal pembinaan pada kegiatan mapenaling sehingga para narapidana baru cenderung tidak ada kegiatan selama program pembinaan mapenaling

Berdasarkan pada fakta di lapangan mengenai program mapenaling yang dilaksanakan menujukkan bahwa perlu adanya evaluasi atas pelaksanaan program pembinaan sehingga tujuan dari program tersebut dapat berjalan dengan optimal. Dari beberapa permasalahan yang ditemui hal tersebut akan menimbulkan hambatan dalam pencapaian tujuan, hal tersebut tentu saja akan berakibat terhadap kurangnya kesadaran diri pada setiap nara pidana yang melaksanakan program pembinaan, waktu penerimaan narapidana baru yang tidak menentu akan menjadikan sulitnya interaksi sosial yang harus dibangun setiap narapidana yang baru dalam melaksanakan mapenaling terhadap narapidana lainnya baik itu dari aspek kerjasama, sosialisasi, mengenal kondisi lingkungannya maupun kesadaran terhadap hak dan larangannya sebagai narapidana. Sebagai upaya mengatasi permasalahan yang ada di Lembaga Pemasyarakatan Kelas IIA Banceuy, perlu adanya pemaksimalkan dalam proses pelaksanaan pembinaan yaitu dengan memberikan inovasi supaya pada narapidana, pembinaan tersebut dapat memaku dan menyemaikan semangat narapidana untuk mengikuti pembinaan mapenaling dengan baik. Selain itu adanya program pembiaan dapat dijadikan sebagai tolak ukur atas keberhasilan pencapaian program pembinaan narapidana yang berada didalam lembaga permasyarakatan. 


\section{Pencapaian}

Pencapaian dalam program pembinaan mapenaling bagi narapidana baru ini adalah :

1. Narapidana dapat mengenal situasi dan kondisi lingkungan lembaga pemasyarakatan, dengan tujuan agar mereka dapat saling mengenal dan beradaptasi dengan lingkungan serta sesama narapidana di lembaga pemasyarakatan tersebut,

2. Narapidana dapat mengikuti program pembinaan dengan sungguh-sungguh sehingga pelaksanaan program pembinan pada tahap selanjutnya menjadi lebih maksimal,

3. Narapidana dapat berpartisipasi secara aktif selama kegiatan pembinaan berlangsung.

4. Narapidana akan mampu menyesuaikan diri dan terbiasa dengan program pembinaan yang dilakukan didalam lapas.

Ketika pelaksanaan program pembinaan yang dilakukan pada mapenaling ini berhasil, maka narapidana akan terbiasa dengan kegiatan pembinaan yang ada di Lembaga Pemasyarakatan kelas II A Banceuy.

\section{SIMPULAN}

1. Pelaksanaan program masa pengenalan lingkungan (mapenaling) di Lembaga Pemasyarakatan kelas IIA Banceuy, diantaranya :

a. Pengenalan lingkungan yang akan dilakukan oleh petugas pembinaan yang akan memberikan pengenalan meliputi penjelasan tentang hak dan kewajiban serta pengenalan terhadap peraturan dan ketentuan yang berlaku.

b. Melakukan assessment untuk mengetahui:

1) Tingkat resiko pengulangan pidana

2) Minat, bakat, keterampilandan keahlian yang dimiliki

3) Mengetahui latar belakang kehidupannya yang akan berguna terhadap perencanaan program pembinaan

c. Melakukan skrining kesehatan atau pemeriksaan kesehatan dasar bagi narapidana baru yang bertujuan untuk mengetahui riwayat kesehatan, serta merupakan bentuk deteksi dini terhadap resiko kesehatan sehingga dapat memberikan informasi sekaligus penanganan yang tepat jika ditemukan resiko terhadap penyakit tertentu. Hal tersebut juga dapat mempengaruhi terhadap penempatan kamar atau kegiatan pembinaan narapidana, contohnya bagi narapidana yang menderita penyakit TBC, HIV/AIDS, infeksi menular seksual,

d. Memberikan wawasan atau penyuluhan dalam bidang kesehatan seperti penyuluhan mengenai bahaya penggunaan narkoba, pencegahan terhadap penyakit menular, serta prilaku hudup sehat. Kegiatan tersebut merupakan upaya untuk mencegah penyakit yang dapat dialami oleh narapidana serta agar narapidana mengetahui dampak buruk dari penggunaan narkoba sehingga mereka akan membiasakan diri dengan prilaku hidup sehat

e. Melakukan pembinaan pada aspek kepribadian pada program ini petugas yang menangani kegiatan mapenaling secara berkesinambungan melakukan kegiatan-kegiatan pembinaan yang bertujuan untuk merubah pola pikir dan kepribadian narapidana sehingga mereka dapat menyadari kesalahan, menerima keadaaan dirinya, dapat mengikuti program pembinaan dengan baik serta akan terbiasa dengan kehidupan yang akan dijalaninya. Upaya pembinaan yang menekankan terhadap aspek kepribadian juga dapat dilakukan melalui kegiatan keagamaan, kegiatan baris-berbaris, pramuka, kesenian, kegiatan jasmani.

2. Terdapat beberapa faktor penghambat proses pelaksanaan program mapenaling yang dilakukan di lembaga pemasyarakatan kelas IIA, seperti :

a. Pembinaan yang dilakukan pada program mapenaling hanya terpaku dalam bidang kesehatan

b. Tidak ada petugas yang memonitoring secara langsung terhadap seluruh kegiatan mapenaling sehingga tidak semua program pembinaan dapat tersampaikan.

c. Waktu penerimaan narapidana yang tidak pasti atau tidak tentu serta kurangnya kapasitas kamar mengakibatkan waktu pelaksanaan mapenaling tidak dapat dilakukan dalam kurun waktu yang lama dan tidak dapat dilakukan dalam waktu yang sama.

d. Tidak adanya jadwal pembinaan pada kegiatan mapenaling sehingga para narapidana baru cenderung tidak ada kegiatan selama program pembinaan mapenaling.

\section{Saran}

Berdasarkan hasil dari penelitian di lembaga pemasyarakatan kelas IIA Banceuy tentang program pembinaan mapenaling terhadap narapidana baru maka terdapat beberapa saran yang kami rangkum sebagai berikut:

1. Adanya inovasi akan bentuk pembinaan narapidana yang dimasukkan kedalam program mapenaling, dimana pembinaan yang dapat menarik dan membangkitkan semangat narapidana untuk mengikuti pembinaan mapenaling dengan baik.

2. Hendaknya petugas juga ikut terlibat dalam memberikan dukungan terhadap pelaksanaan program ini, baik dukungan yang bersifat finansial, moral, sarana, maupun prasarana dan memantau perkembangan narapidana selama mengikuti 
program mapenaling. Seperti adanya jadwal petugas yang dilakukan secara bergantian untuk memberikan pembinaan kepada narapidana baru

3. Petugas lapas kelas IIA banceuy harus melakukan koordinasi dengan lapas, rutan atau pihak lainnya terkait dengan penerimaan tahanan atau narapidana baru sehingga tidak terjadinya penumpukan narapidana baru pada tahap mapenaling yang akan mengakibatkan waktu pelaksanaan mapenaling berbeda-beda dan program pembinaan pada tahap mapenaling tidak dapat tersampaikan secara optimal.

4. Adanya jadwal rutin dalam pelaksanaan program mapenaling sehingga setiap pelaksanaan kegiatan akan berjalan dengan baik dan terarah.

\section{DAFTAR PUSTAKA}

Adi Sujatno, 2008, Pencerahan di Balik Penjara, Jakarta: Sinar Grafika.

Dwidja Priyanto, Sistem Pelaksanaan Pidana Penjara di Indonesia, (Bandung: PT. Rifka Aditama, 2009), hlm. 103. https://zhernia.files.wordpress.com/2010/06/penyimpangan-sosial.pdf

Kontribusi keberhasilan pembinaan narapidana di indonesia. (2016). umi enggarsasi. Kontribusi keberhasilan pembinaan narapidana di indonesia.

Peraturan pemerintah nomor 31 tahun 1999. (1999, january 31). Undang undang pemasyarakatan. Retrieved from https://jdih.bpk.go.id/wp-content/uploads/2012/03/PP311999.pdf.

Priyatno. (2006). Sistem Pelaksanaan Pidana Penjara di Indonesia. Bandung: PT Refika Aditama.

Sarli Zulhendra, Panduan Hukum: pengetahuan tentang aparat Penegak Hukum.http://www.solider.or.id/2014/07/14/panduan-hukum-pengetahuan-tentang-aparat penegak hukum.

Sistem pembinaan. (2013, maret 12). p. http:/repository.unpas.ac.id/14819/4/BAB\%20II.pdf.

Tim Peneliti BPHN dan FISIP UI, 1988, Aspek-aspek yang Mempengaruhi Penerimaan Bekas Narapidana dalam Masyarakat. Laporan Penelitian, Jakarta: Badan Pembinaan Hukum Nasional Departemen Kehakiman, hlm. 16.

Undang-undang Republik Indonesia Nomor : 12 Tahun 1995 tentang Pemasyarakatan

Rizky Argama. Tanggung Jawab Profesi Hakim Sebagai Aktor Utama Penyelenggara Kekuasaan Kehakiman Di Indonesia. Makalah Mahasiswi Fakultas Hukum Universitas Indonesia, halaman 12. 2006

Tupanto AP. Analisis Dasar Pertimbangan Hakim Dalam Menjatuhkan Sanksi Pidana Tindak Pidana Perbuatan Tidak Menyenangkan (Studi Kasus Perkara No. 39/Pid. B/2010/PN. Mgl).

Widiartana, G. Silabus Etika dan Tanggung Jawab Profesi, Universitas Atma Jaya, hlm. 9. 2009

Wildan Suyuthi Mustofa. Kode Etik Hakim. Jakarta: Prenadamedia Group, halaman 56. 2013

Wildan Suyuthi Mustofa. (Selannjutnya disebut Wildan II). "Etika Profesi, Kode Etik, dan Hakim dalam Pandangan Agama," dalam Pedoman Perilaku Hakim (Code of Conduct), Kode Etik Hakim dan Makalah Berkaitan. Jakarta: Mahkamah Agung RI, halaman 34-35. 2006. 